Online Journal of Language and Literature

\title{
KHAT NASKHI'S WRITING AND ARTISTIC TECHNIQUES IN CALLIGRAPHY LEARNING
}

\author{
Siti Aliyya Laubaha ${ }^{1}$ Zikra M. Umar $^{2}$ \\ 1wiyalaubaha@gmail.com ${ }^{2}$ zikramumar73@gmail.com \\ Pendidikan Bahasa Arab, IAIN Sultan Amai Gorontal, Indonesia
}

\section{ARTICLE INFO}

\section{Article history: \\ Received 15 March 2020 \\ Accepted 1 April 2020 \\ Available online 28 April 2020}

\section{Key Word \\ Khat Naskhi \\ Artistic Techniques \\ Calligraphy Learning \\ Naskbi's Writing \\ @2020 Ojolali ltd \\ All Rights Reserved}

\begin{abstract}
A B S T R A C T
The research examines the procedures for writing khat naskbi and the beauty of writing in calligraphy learning. This research is library research, the data collected is based on a critical and in-depth assessment of the relevant library materials. Primary data sources are Mushaf, calligraphy books, rasm, khat and imla. Data collection techniques are carried out by; read, recording, identifying, tabulating, analyze and conclude. The results of this study indicate that the technique of writing khat naskbi is very easy for beginners, because it has a simple cursive geometric shape, and does not highlight variations other than letters and diacritical marks. This type of khat is also very familiar to use in writing manuscripts so that it is in great demand by Arabs and non-Arabs because its shape can be distinguished by several signs, namely, the writing is easy to read, has a horizontal line reference, has simple punctuation marks and has four styles, namely: 1) Tarsif, 2) Ta'lif, 3) Tastir and 4) Tanshil.
\end{abstract}

\section{A. Introduction}

Tulis menulis suatu naskah tentunya juga melibatkan khat atau kaligrafi Arab. Dalam dunia teks memang sudah ada sejak zaman Nabi Muhammad saw. Kaligrafi adalah salah satu seni Islam yang khususnya berkaitan dengan tulis menulis yang memiliki sejarah dalam kitab suci al-Quran yang mengiringinya. ${ }^{1}$

Pengertian seni khat dapat dilihat dalam dua pengertian, yaitu pengertian secara etimologi dan terminologi. Pengertian etimologi, kata khat lebih popular dan dikenal dengan seni kaligrafi Islam yang merupakan penyederhanaan daripada kata calligraphy, berasal dari dua suku kata bahasa Yunani yaitu Kallos: beauty (indah) dan Graphein: to write (menulis). ${ }^{2}$ Yang berarti yaitu "seni menulis dengan indah, tulisan tangan yang menghasilkan huruf atau tulisan indah sebagai suatu seni; khat." Adapun makna seni khat adalah "seni (kemahiran) menulis tulisan Arab atau tulisan jawi dengan gaya khas atau unik sehingga menghasilkan tulisan indah."

Pengertian lain seni ini ialah "seni menulis indah dengan pena." disebut juga Fann al-Khat dalam artian seni memperhalus tulisan atau memperbaiki coretan. Pengertian tersebut, dapat dipahami bahawa seni khat merupakan tulisan yang ditulis indah dengan menggunakan ortografi Arab sebagai tulisan asas. ${ }^{3}$ selain diikuti dengan corak hiasan dan motif yang menarik sehingga memunculkan seni tulisan cantik dan

${ }^{1}$ Maryono, Nilai-nilai Pendidikan Dalam Seni Kaligrafi Karya Syaiful Adnan, Jurnal Studi Keislaman Vol. 4, No. 1 April 2018, hal. 1-2.

2 Ibnu Rawandhy N Hula, 'Preferensi Abu Dawud Sulaiman Bin Najjah Dalam Kaidah Rasm Al-Mushaf/Preference of Abu Dawud Sulaiman Bin Najjah In Rules of Rasm Al-Mushaf, Diwan: Jurnal Bahasa Dan Sastra Arab, 6.2 (2020) <https://doi.org/https://doi.org/10.24252/diwan.v6i2.13969>.

3 Ibnu Rawandhy N Hula, 'Ortografi Alif Ziyadah Dalam Rasm Mushaf Madinah Pada SUrah Al-Baqarah' (Malang: Jurusan Sastra Arab - Fakultas Sastra UniversitasNegeri Malang, 2020), pp. 945-65 <http://prosiding.arabum.com/index.php/konasbara>. 
indah untuk dinikmati sebagai karya seni yang unik dan menarik ${ }^{4}$ Menurut pengertian istilah (terminologi) pula, seni ialah segala yang halus dan indah lagi menyenangkan hati serta perasaan manusia, apakah ia merupakan hasil cipataan Allah swt maupun yang dihasilkan oleh pikiran, kemahiran, imajinasi dan perbuatan seorang manusia.

Dalam hal ini, seni kaligrafi dipandang seni yang kedua setelah arsitektur. Hal ini disebabkan karena seni figurative haram hukumnya, maka kaligrafi menjadi seni yang paling digemari dan paling maju ketimbang seni-seni lainnya. Ini juga tentunya dalam agama Islam merupakan suatu peradaban yang didasarkan pada tulisan dan perkataan Allah sebagaimana yang tercantum dalam al-Quran, sehingga seni tulisan ini adalah seni tulisan yang mengandung sifat yang agung. ${ }^{5}$

Secara harfiyah seni kaligrafi ditakrifkan oleh ibnu khaldun dalam bukunya al-Muqaddimah "kaligrafi adalah lukisan dan bentuk harfiyah yang menunjukkan kepada kalimat yang didengar yang mengisyaratkan apa yang ada di dalam jiwa". Kaligrafi Islam indonesia sejak dari tanah asalnya merupakan salah satu parameter peradaban yang berkembang seirama dengan tumbuh dan berkembangnya agama Islam. Dan seni kaligrafi Islam indonesia merupakan salah satu parameter eksistensi peradaban (tamaddun) Islam di indonesia dan di beberapa Negara Asean?

Terkait dengan hal di atas, kaligrafi sebagai salah satu seni Islam bidang tulis-menulis memiliki aspek sejarah yang kuat dalam mengiringi kitab suci al-Qur'an. Ia merupakan visualitas dari ayat-ayat Allah subhanahu wa ta'ala dalam lingkup mikro, sedangkan alam dan isinya merupakan realitas makro ayat-ayat al-Qur'an. Jenis khat atau kaligrafi yang dominan serta menjadi standar penulisan al-Qur'an adalah gaya khat Kufi yang belum ada tanda baca (ijam $)^{8}$ atau diakritik. ${ }^{9}$ Jenis khat atau kaligrafi yang dominan serta menjadi standar penulisan al-Qur'an adalah gaya khat Kufi yang belum ada tanda baca (i'jam).

Pada masa berikutnya Al-Khalil Ibn Ahmad (w. 786 M) berhasil melengkapi penemuan para ahli sebelumnya sehingga mencapai tahap kesempurnaan, seperti tulisan yang kita lihat dan kita baca saat ini, yakni bentuk utama huruf, titik huruf serta harakat atau syakal. ${ }^{10}$ Selanjutnya pada periode mulai dari akhir pemerintahan Bani Umayah (661 - 705 M) hingga pertengahan kekuasaan Bani Abbasiyah di Baghdad, yaitu pada khalifah al-Makmun ditemukan enam rumus pokok kaidah khat Al-Aqlam as-Sittab ${ }^{11}$ (enam tulisan pokok) yaitu Tsuluts, Naskh, Muhaqqaq, Raibaniy, Riq'iy atau Riq'ah, dan Tauqî." ${ }^{12}$

Gaya Masyq dan Naskh terus berkembang, sedangkan Mail lambat laun ditinggalkan karena kalah oleh perkembangan Kufi. Perkembangan Kufi pun melahirkan beberapa variasi baik pada garis vertikal maupun horizontalnya, baik menyangkut huruf-huruf maupun hiasan ornamennya. Muncullah gaya Kufi Murabba' (lurus-lurus), Muwarraq (berdekorasi daun), Mudhaffar (dianyam), Mutarabith Mu'aqqad (terlilit berkaitan) dan lainnya. Demikian pula gaya kursif mengalami perkembangan luar biasa bahkan mengalahkan gaya $K u f i$, baik dalam hal keragaman gaya baru maupun penggunannya, dalam hal ini penyalinan al Quran, kitab-kitab agama, surat- menyurat dan lainnya.

Salah satu bidang kesenian yang sangat menakjubkan adalah seni khat atau kaligrafi. Khat ini, berkembang dari masa satu ke masa yang lain hingga menyebabkannya menjadi terkenal dan banyak diminati oleh para penggiat seni yang menyukai tulisan dalam lingkungan masyarakat Islam. Seni khat, lebih fokus pada hasil tulisan yang menggunakan bermacam-macam gaya dan corak yang menghasilkan

${ }^{4}$ Harun Makmur and Yusof Abdullah, 'Manifestasi Khat Naskhi Sebagai Tulisan Asas Al-Quran: Kajian Terhadap Jenis Khat Naskhi Sebagai Tulisan Asas Al- Quran Mushaf Uthmani’, January, 2011.

${ }^{5}$ Pujiati Kaligrafi Arab Digital ayat al-Qur'an di Dunia Maya Jurnal Miqot Vol. No. 1 Januari-Junia 2016, hal. 221 -

222

${ }^{6}$ Makmur Haji Harun, 'EKSISTENSI SENI KALIGRAFI ISLAM DALAM DAKWAH : Tantangan, Peluang Dan Harapan.', October, 2015, 0-18 < https:/ /doi.org/10.13140/RG.2.1.2949.8320>.

${ }^{7}$ Ibnu Rawandhy N Hula, Qawaid Al-Imla' Wa Al-Khat 1, 2015.

${ }^{8}$ Nurul Huda, 'Implementasi Jenis Khat Naskhi Dalam Pembelajaran Bahasa Arab', Al Mahāra: Jurnal Pendidikan Bahasa Arab, 3.2 (2017), 291-316 <https://doi.org/10.14421/almahara.2017.032-06>.h.289

${ }^{9}$ Ibnu Rawandhy N Hula and others, 'Diakritik Al-Quran Menurut Preferensi Abu Dawud', 'A Jamiy: Jurnal Bahasa Dan Sastra Arab, 9.2 (2020), 265-84 <https://doi.org/http://dx.doi.org/10.31314/ajamiy.9.2.264-284.2020>.

${ }^{10}$ Ibnu Rawandhy N Hula, 'Preferensi Abu Dawud Sulaiman Bin Najjah Dalam Kaidah Rasm Al-Mushaf/Preference of Abu Dawud Sulaiman Bin Najjah In Rules of Rasm Al-Mushaf'.

${ }^{11}$ Ibnu Rawandhy N. Hula, 'AL-QAWAID AL-SITTAH DALAM RASM AL-MUSHAF (Kajian Teoritis Terhadap Enam Kaidah Pokok Dan Keunikannya Dalam Penulisan Al-Qur’an)’, ed. by Ana Mariana (Gorontalo), pp. 1-33.

${ }^{12}$ Ibnu Rawandhy Hula, 'GENEALOGI ORTOGRAFI ARAB (Sebuah Tinjauan Historis: Asal-Usul, Rumpun Bahasa Dan Rekaman Inskripsi)', Http://Journal.Umgo.Ac.Id/Index.Php/AJamiy/Index, $9.1 \quad$ (2020), 16-46 <https://doi.org/DOI: http://dx.doi.org/10.31314/ajamiy.9.1.16-46.2020>. 
berbagai macam huruf, ayat, serta kalimat yang ditulis sedemikian rupa, baik itu sistematik, indah, dan menghasilkan suatu tulisan yang sangat sermpurna. Untuk itu dalam artikel penulis hanya memfokuskan pada pada teknik penulisan dan artistik khat naskbi.

\section{B. Method}

Penelitian ini merupakan penelitian kepustakaan, data dikumpulkan berpijak pada pengkajian kritis dan mendalam terhadap bahan-bahan pustaka yang relevan. Bahan-bahan pustaka ini diposisikan sebagai sumber primer. Sumber data primer adalah Mushaf, buku-buku kaligrafi, rasm, khat dan imla. Teknik pengumpulan data dilakukan dengan cara, membaca, mencatat, mengidentifikasi, mentabulasi, menganalisis dan menyimpulkannya.

\section{Discussion}

Kata Naskh diambil daripada akar kata Nuskhah atau Naskah yang berarti naskah karena ia banyak dipakai untuk menyalin terjemahan naskah-naskah Yunani, Parsi dan lain sebagainya. Khat Naskhi ialah tulisan tangan yang berbentuk cursif atau tulisan bergerak berputar (rounded) dan sifatnya mudah serta jelas untuk ditulis dan dibaca. ${ }^{13}$ Dalam bukunya Koleksi Karya Master Kaligrafi Islam bahwa khat Naskbi adalah tulisan yang sangat lentur dengan banyak pusingan dan hanya memiliki sedikit sudut yang tajam seperti sudut-sudut Küfi. Seiring dengan namanya kata Naskbi secara etimologis adalah berasal dari kata kerja nasakha-yansukhu yang berarti telah menghapus.

Dalam sejarah kaligrafi Islam tulisan bentuk Naskhi merupakan tulisan kursif (tulisan miring) yang pertama kali timbul, yang rumus-rumus dasarnya ditemukan oleh seorang kaligrafer ternama yang bernama Ibnu Muqlah (w. $328 \mathrm{H}$ ) di Iraq. ${ }^{14}$ Kemudian hari khat Naskbi menjadi populer setelah dirancang kembali pada abad ke-10 oleh Ibnu Bawwab dan Ya'qut al-Musta'simi serta para pakar lainnya hingga resmi menjadi tulisan resmi al-Quran. Ia dianggap sebagai penutup khattat generasi Baghdad. Yaqut dijuluki Qiblah al-Khattatin karena saat itu para khattat dari dunia Islam bukan hanya dari Arab tapi juga dari Persia dan Turki belajar darinya khat yang enam. ${ }^{15}$

Kata ini diartikan demikian karena jenis tulisan ini telah menghapus atau mendesak tulisan yang telah ada sebelumnya, yaitu Kufi. Tulisan khat Naskbi setelah lepas dari tulisannya yang kuno sebelum masa kenabian. Kemudian gaya tulisannya yang semakin sempurna tersebut digunakan untuk urusan administrasi perkantoran dan surat menyurat di zaman kekuasaan Islam. Pada abad ke-3 dan ke-4 hijriuyah, pola-pola Naskhi bertambah indah dengan kodifikasi yang dibuat Ibnu Muqlah. Para ahli sejarah beranggapan, bahwa Ibnu muqlah adalah peletak dasar khat Naskhi dalam bentuknya yang sempurna pada zaman Abbasiyah. ${ }^{16}$

Dikatakan pertama kali yang menggunakan khat ini adalah Ali bin Abi Thalib. Tetapi, pendapat yang lebih rajih menyebutkan bahwa yang menciptakannya adala Ibnu muqillah, sejak abad ke-6 Hijriyah, khat tersebut menggantikan khat Kufi dalam penggunaannya. Diantara keistimewaan khat Naskbi adalah adanya harakat dan huruf-hurufnya bisa dipanjangkan ${ }^{17}$.

Pada zaman kekuasaan Atabek Ali usaha memperindah khat Naskhi mencapai puncaknya sehingga terkenalah gaya yang disebut Naskhi Atabek yang banyak digunakan menyalin mushaf al-Quran di abad pertengahan Islam. Khat ini disebut dengan khat Naskhi karena para khattat menulis al-Quran dan berbagai buku dengan menggunakan gayanya. Ciri-cirinya ialah mempunyai kelembutan, mudah dibentuk, praktikal dan mudah dibaca. Ukuran untuk khat Naskbi: huruf alif tingginya lima titik. Dan yang tidak

13 Furqon Nurhidayat, Juju Masunah, and Tri Karyono, 'Arabic Calligraphy in the Art of Glass Painting From Cirebon by Raffan S. Hasyim', 519.Icade 2020 (2021), 52-56 <https://doi.org/10.2991/assehr.k.210203.011>.

${ }_{14}$ Ali Fitriana Rahmat, 'Ibnu Muqlah (W. 328 H): Sejarah Dan Sumbangsihnya Dalam Penulisan Al-Qur'an', Jurnal Al-Fanar, 4.1 (2021), 45-62 <https://doi.org/10.33511/alfanar.v4n1.45-62>.

15 Perkembangan Kaligrafi Dan and Abdul Hakim, 'The Development Of Islamic Calligraphy And Its Urgency For

The Qur' Anic Manuscripts', Jurnal Lektur Keagamaan, 19.1 (2021), 69-102 < https://doi.org/10.31291/jlk.v19i1.911>.

16 Abd. Aziz Ahmad, 'Contemporary Islamic Calligraphy Learning', 519.Icade 2020 (2021), 232-36

<https://doi.org/10.2991/assehr.k.210203.049>.

${ }^{17}$ Usman, 'Korelasi Penguasaan Kaligrafi (Khat Arab) Dengan Kterampilan Menulis Bahasa Arab Siswa Kelas VII MTs Darul Muhajirin Putra Praya Lombok Tengah Tahun Pelajaran 2016-2017', Вестник Росздравнадзора, 2017.h.19 
kalah uniknya huruf satu terbentuk dari huruf lainnya, maka bila ingin belajar khat ini harus menguasai dari yang pertama, karena akan berpengaruh pada huruf-huruf berikutnya.

Berikut perinciannya, bagian pertama adalah huruf-huruf diatas garis-garis sebagai berikut: ${ }^{18}$

1. Huruf alif (dan semua yang terbentuk darinya - ا- ك- ط- ל- (1)

2. Huruf $\mathrm{Ba}, \mathrm{Ta}, \mathrm{Ts} a$, (hanya beda peletakan titik) dan badan huruf $\mathrm{Fa}$

3. Huruf Dal, Dral, dan awal huruf $H a$

4. Huruf Tho dan D₹ho (perutnya berasal dari Shod badannya dari Alif)

5. $F a$ (kepalanya $W$ au badannya $B a)$

6. $\operatorname{Kaf}$ (dari alif)

7. Kaf model kedua

8. Ha (dari Dal)

9. Lam alif

Kata tersebut juga mengandung arti menyalin hal itu disebabkan tulisan tersebut biasanya untuk menulis, menyalin mushaf al-Qur'an, kitab-kitab agama lainnya dan naskah ilmiah. Dari arti menyalin ini dimungkinkan pula bahwa kata 'naskah' dalam Bahasa Indonesia berasal dari kata kerja nasakha - yansukbu yang berarti telah menyalin. Ada pula penafsiran yang mengartikan nasakha adalah melengkung (cursive) karena bentuk hurufnya cenderung melengkung yang secara langsung membedakannya dengan tulisan Kufi yang kaku bersudut (anguler).

Khat Naskhi dipakai untuk mushaf al-Qur'an dan menjadi khat dari teks- teks Arab yang lain, khat ini juga sering disebut dengan khat jusnalistik (khat Shubufi). Tulisan khat Naskhi merupakan tulisan kursif yang pertama kali timbul. oleh Ibnu al-Bawwab dan pakar lainnya hingga resmi menjadi tulisan al-Qur'an. Hingga saat ini tulisan al-Qur'an atau Hijaiyah adalah identik dengan gaya Naskbi, rasm Mushaf Utsmani ${ }^{19}$ juga menggunakan Naskhi. Dengan kata lain, model khat Naskhi yang paling banyak digunakan dalam dunia Islam, karena mudah dalam menuliskannya maupun membacanya.

Dalam khat Naskhi tidak ada kekhususan penulisan, kecuali pada kepala 'ain dan mim akhir dari jenis mursal (kejur, terjuntai) yang proses penulisannya: 'ain dilukis persis seperti proses penulisan yang diterapkan pada huruf 'Ain dalam khat Tsuluts. mim dilukis (ditulis) hanya dengan menggunakan pena untuk huruf pokok (satu pena) saja, tetapi harus diperhatikan terutama ketika memiringkan mata pena, yang pada permulaan huruf ditulis dengan menggunakan sepertiga leher mata pena. Selanjutnya pena kembali menapak penuh dalam menggoreskan ujung huruf, sehingga melahirkan huruf sebagai berikut:

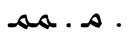

Menurut Hasyim ada namanya Khat Naskhi, Khat ini biasanya dipelajari lebih dahulu sebelum belajar jenis khat yang lain. Karena memang sangat cocok dijadikan sebagai dasar dalam mempelajari kaligrafi Arab. Sesuai dengan namanya Naskbi karena tulisan jenis ini sering dipakai dalam tulisan-tulisan naskah berbahasa arab dan juga dalam penulisan Mushab Al Qur'an.

Adapun ciri-ciri dari jenis Khat Naskbi ini diantarnya adalah:

1. Huruf-hurufnya mudah dipahami dan dikenal, baik oleh orang awam (yang tidak mengerti kaligrafi) sekalipun.

2. Tulisan Arab/al-Quran yang menggunakan jenis khat Naskhi pasti bisa dibaca oleh orang yang mampu membaca al-Quran/huruf Arab.

3. Menggunakan garis acuan horizontal sehingga dari garis tersebut ada huruf yang berada diatas garis dan ada huruf-huruf yang memotong garis.

4. Panjang, lebar, dan besar huruf khat Naskbi disesuaikan dengan alat tulis yang dipakai, dalam rumus khat Naskhi para ahli membuat tinggi dari huruf alif adalah lima titik dari ukuran pena.

5. Harakat/tanda baca dalam jenis khat Naskhi tepat berada diatas huruf jika baris fathah dan sukun dan berada dibawah huruf jika berada dibaris kasrah.

6. Penulisan tasjid (siddah) dari pariasi dalam khat Naskbi ditulis dengan pena yang lebih kecil dengan pena huruf tunggal.

${ }^{18}$ Ibnu Rawandhy N Hula, Qawaid Al-Imla' Wa Al-Khat 1.h.212

${ }^{19}$ Ibnu Rawandhy N Hula, 'Ortografi Alif Ziyadah Dalam Rasm Mushaf Madinah Pada SUrah Al-Baqarah'. 
7. Dalam penulisan khat Naskhi, huruf-huruf hijaiyah yang berjumlah 29 sebagian tulisannya terdapat kesamaan antara satu dengan yang lainnya ${ }^{20}$.

Khat Naskhi mempunyai bentuk tulisan sederhana yang tidak terlalu rumit dalam penulisaanya, memikat, mudah dibaca dan mudah untuk dipelajari dan ditulis, sehingga banyak buku-buku ilmiah yang ditulis menggunakan khat naskhi. Jenis khat Naskhi ini menjadi tulisan utama dalam penulisan al-Quran standar maupun al-Quran mushaf Uthmani. Peranan khat Naskhi dalam tulisan al-Quran menjadikan jenis khat ini terus berkembang dan bahkan terus diperlukan dengan menggunakan kaidah yang lebih baik. Secara keseluruhan, Khat Naskbi dibagi kepada 2 jenis:

\begin{tabular}{|c|c|}
\hline Khat Naskbi Qadim & Khat Naskbi Subufi \\
\hline $\begin{array}{l}\text { Naskhi qadim atau kuno adalah gaya tulisan } \\
\text { yang sampai pada kita dari zaman Bani Abbas, } \\
\text { kemudian diperintah oleh Ibnu Muqlah dengan } \\
\text { kodifikasinya, kemudian diperindah lagi oleh } \\
\text { masyarakat Atabek. Lalu diolah menjadi karya } \\
\text { seni yang semakin sempurna oleh orang-orang } \\
\text { Turki. Sehingga sampailah kepada kita } \\
\text { sekarang dengan bentuk-bentuk yang indah. } \\
\text { Sekarang para kaligrafi menulis secara } \\
\text { tradisional karena mengikuti kaidah-kaidah dan } \\
\text { asal-muasal yang lama, mencakup ukuran, } \\
\text { ketinggian, tipis-tebal garis horizontal dan } \\
\text { vertikal, serta bentuk lengkungannya. }\end{array}$ & $\begin{array}{l}\text { Naskbi suhufi atau jurnalistik merupakan gaya } \\
\text { yang terus berkembang bentuk huruf-hurufnya. } \\
\text { Dinamakan suhufi karena penyebarannya yang } \\
\text { luas dilapangan jurnalistik. Maskhi suhufi } \\
\text { cenderung kaku dan pada beberapa bagian } \\
\text { mendekati bentuk Kufi karena memiliki sudut } \\
\text { yang tajam, berbeda dengan Naskhi qadim yang } \\
\text { lebih lentur dengan banyak putaran. }\end{array}$ \\
\hline
\end{tabular}

Gaya tulisan ini kerap disebut Naskbi-Kufi (perpaduan Naskbi-Kufi) dengan ciri umum sapuan horizontalnya sangat tebal dan sapuan vertikalnya sangat tipis dan pendek (3-5 titik). Naskhi Kufi banyak digunakan dilapangan advertensi, plakat, poster, dan judul-judul tulisan dikoran dan majalah, jenis ini telah masuk lingkup alfabet komputer sehingga jarang ditulis langsung oleh tangan ${ }^{21}$

Tidak ada kekhususan dalam menulis khat Naskhi, hanya saja kepala "ain dan mim akhir dari jenis mursal (terulur atau kejur). Cara menulis khat Naskhi adalah sebagai berikut: "Ain dilukis persis seperti cara yang diterapkan untuk "ain Tsuluts. Mim ditulis hanya dengan pena untuk huruf pokok itu saja, namun harus diperhatikan terutama dalam memiringkan pena. Permulaan huruf ditulis dengan hanya sepertiga lebar pena tersebut. Selanjutnya pena kembali menapak penuh dalam menggoreskan ujung huruf.

Khat Naskhi dianggap script yang tertinggi untuk hampir semua umat Islam dan Arab di seluruh dunia. Khat ini biasanya ditulis dengan batang horizontal pendek dengan kedalaman vertikal hampir sama di atas dan dibawah garis medial. Khat jenis ini merupakan khat khat yang sangat elastic karena bentuk kelenturan yang sangat stabil karena tulisan Naskbi ini merupakan suatu jeni cursif, yakni tulisan bergerak berputar (rounded) mirip busur atau berbentuk setengah lingkaran yang sifatnya mudah untuk dibaca.

Ibnu Muqlah merumuskan empat ketentuan tentang tata cara dan tata letak yang sempurna pada tulisan khat Naskhi berikut ini:

${ }^{20}$ D A R El and others, 'Kemampuan Santri Dalam Menulis Khat Naskhi Pada Pelajaran Kaligrafi Di Madrasah Tsanawiyah Pondok Pesantren Dar El Hikmah Pekanbaru’, 2010.h.8.

${ }^{21}$ M Mawardi, 'Penerjemahan Komunikatif Buku Asrar Al-Rasm Fi Khat Al-Naskhi Karya Mohamed Amzil', Skripsi, 2012, 1-154.h.28 


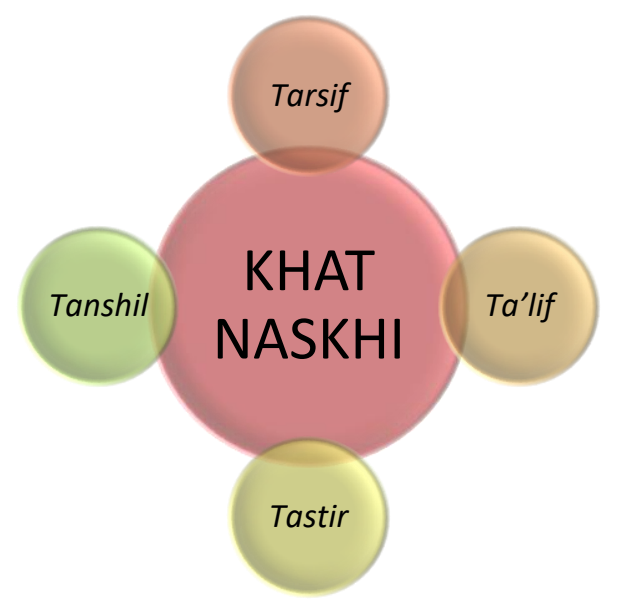

1. Tarsif ترصيف (jarak huruf rapat dan teratur),

2. Ta'lif تأليف (susunan huruf terpisah dan bersambung dalam bentuk serasi),

3. Tastir تسطبر (keselarasan dan kesempurnaan hubungan satu kata dengan lainnya dalam sau garis lurus),

4. Tansil تنصيل (melukis keindahan dalam setiap sapuan garis pada setiap hurufnya).

Peranan Khat Naskhi dalam tulisan al-Qur'an menjadikan jenis khat ini terus berkembang dan bahkan terus di perhalus dengan menggunakan kaidah yang lebih baik lagi sebagai tulisan dan hiasan dalam menghasilkan Mushaf al-Qur'an. Selain itu juga menjadi isyarat keindahan tulisan dalam berbagai mushaf terutama Mushaf Uthmani. ${ }^{22}$ Khat Naskhi ini juga telah mengungkap ketelitian bidang seni khat dengan pembahasan dan penggunaannya yang sangat mendalam. Selain itu, khat ini telah dijadikan sebagai gambaran artistik yang direalisasikan melalui sentuhan tangan-tangan kreatif kaligrafer maupun seniman terhadap berbagai bahan dan medium.

Karakter dari khat Naskhi adalah lengkungan-lengkungan hurufnya mirif busur atau berbentuk setengah lingkaran, seperti huruf nun, wawn, ra' dan $z a$ ', sebagian huruf-hurufnya diletakkan diatas garis semi, seperti huruf alif, dal, ba', kaf dan fa dan sebagian lainnya menukik melabrak batas-batas garis, huruf ra' za', wawu, lam, dan mim, sehingga terlihat menggantung ${ }^{23}$. Keindahan khat ini disebabkan karena adanya iringan harakat atau syakal walaupun pembentukannya sederhana, khat jenis ini merupakan khat yang sangat elastic karena bentuk kelenturan yang stabil karena tulisan Naskhi ini merupakan suatu jenis tulisan bentuk curcif. ${ }^{24}$

Dalam pembelajaran kaligrafi diseluruh dunia, khat Naskbi adalah yang pertama diajarkan kepada murid. Menguasai khat Naskbi, dijadikan standar sebelum si murid mempelajari khat lainnya. Khat ini mencapai puncak kesempurnaannya dan keindahannya pada abad ke-5 Hijriyah di Turki hingga pernah menggeser kedudukan tulisan Kufi pada saat itu. Jenis khat yang lazim dipakai hampir semua teks arab yang beredar dan banyak dijumpai pada buku-buku teks tulisan Arabnya menggunakan gaya khat naskhi. Gaya tersebut seakan telah ditetapkan menjadi khat standar dalam pemakaiannya, serta mampu menjadi dasar atau pokok bagi pembentukan jenis kalgrafi lain. Sebab, gaya atau jenis lain tergolong lebih rumit dalam pembentukan hurufnya dan aspek keterbacaannya lebih sulit dibandingkan dengan jenis khat naskhi.

Dalam proses pembelajaran khat Naskhi merupakan satu-satunya jenis yang paling sederhana, mudah dibaca, dan menjadi dasar untuk tulisan Arab. Khat jenis ini memiliki hubungan dengan bahasa Arab dalam bentuk pembelajaran secara keseluruhan, khususnya pada kemahiran menulis tingkat dasar. Dalam hal ini peranan khat Naskhi dalam pembelajaran bahasa arab dapat dirumuskan sebagai berikut:

1. Khat Naskhi membantu proses kegiatan pembelajaran bahasa Arab, karena dengan menggunakan khat jenis ini dalam proses pembelajaran dengan kesederhanaan dan kelebihannya maka terciptalah pembelajaran yang mudah dan terarah antara guru dan siswa denan komunikasi tulisan yang dapat diterima dengan baik.

2. Khat Naskhi membantu keterampilan menulis (maharatul kitabah) dalam bahasa Arab dasar. Karena keterampilan menulis huruf-huruf tunggal dalam bahasa Arab dan penyambungannya, baik ketika diawal, di tengah, maupun ketika di akhir. Artinya kerampilan menulis huruf hija' termasuk dalam keterampilan dasar dalam menulis mata pelajaran khat. Kterampilan menulis

22 Ibnu Rawandhy N. Agussalim Beddu Mala Hula, 'الفروق الضبطية بين الرسم المصحفى والرسم الإملائي', Al-Lisan: Jurnal Bahasa (e-Journal), 6.1 (2021), 85-111 <https://doi.org/https://doi.org/10.30603/al.v6i1.1930>.

23 Ana Shoimah Itsnaini, 'Peran Pembelajaran Kaligrafi Dalam Melestarikan Seni Budaya Islam', Journal of Chemical Information and Modeling, 53.9 (2013), 1689-99 <https://doi.org/10.1017/CBO9781107415324.004>.h.42.

${ }^{24}$ Ibnu Rawandhy N Hula, Qawaid Al-Imla' Wa Al-Khat : Kaidah-Kaidah Menulis Huruf Dan Kata Arab Dan Seni Kaligrafi (IAIN Sultan Amai Gorontalo, 2016) h. 150. 
dengan jelas dan mudah dibaca sangat membantu keterampilan menulis bahasa Arab pada tingkat dasar.

3. Khat Naskhi membantu keterampilan membaca (maharatul qiraah) dalam bahasa Arab dasar. Karena keterampilan membaca tidak mungkin terwujud tanpa dikuasainya keterampilan mengenal huruf. Mengenal huruf adalah tahap pertama keterampilan membaca dalam bahasa Arab. Dalam pembelajaran khat yang bertujuan untuk mewujudkan keterampilan menulis jelas dan mudah sangat membantu pembelajaran bahasa Arab dasar. Jika peserta didik mampu menulis dengan jelas, mudah dibaca oleh siapa saja, maka artinya ia sendiripun bisa membacanya.

4. Khat Naskhi berperan dalam pembelajaran mufradat siswa. Karena media kaligrafi dapat dimasukkan atau dikelompokkan ke dalam kelompok media pandang (visual) yang berupa tulisan dan gambar, terutama dipakai untuk pembelajaran mufradat (kata-kata baru yang perlu diketahui). ${ }^{25}$

Naskhi banya disukai orang, sebab ditulis lebih mudah dengan bentuk geometrikal kursif yang bergerak memutar dan mudah dibaca tanpa macam-macam struktur yang kompleks. Rumus-rumus yang digunakan dalam penulisan khat Naskhi menurut tarikh klasik Islam, sama dengan yang digunakan untuk sulus dengan standar empat lima titik untuk alif ${ }^{26}$ pada awal kemunculannya, jenis kaligrafi Arab ini disebut "badi". Kaligrafi Arab Naskbi ini memiliki karakteristik lembut, dan jelas dibaca. Apalagi bila kemudian diberi syakal dan titik. Naskhi tidak digunakan dalam bentuk "Tarkib”, melainkan datar mengikuti garis.

\section{Conclusions}

Khat Naskhi dipakai untuk mushaf al-Qur'an dan menjadi khat dari teks- teks Arab yang lain, khat ini juga sering disebut dengan khat jusnalistik (khat Shubufi). Tulisan khat Naskbi merupakan tulisan kursif yang pertama kali timbul. oleh Ibnu al-Bawwab dan pakar lainnya hingga resmi menjadi tulisan al-Qur'an. Hingga saat ini tulisan al-Qur'an atau Hijaiyah adalah identik dengan gaya Naskbi, rasm Mushaf Utsmani juga menggunakan Naskbi.

Khat Naskhi dibagi kepada 2 jenis: a) Khat Naskbi qadim atau kuno adalah gaya tulisan yang sampai pada kita dari zaman Bani Abbas, kemudian diperintah oleh Ibnu Muqlah dengan kodifikasinya, kemudian diperindah lagi oleh masyarakat Atabek, b) Naskbi suhufi atau jurnalistik merupakan gaya yang terus berkembang bentuk huruf-hurufnya. Dinamakan suhufi karena penyebarannya yang luas dilapangan jurnalistik.

Dalam pembelajaran kaligrafi Ibnu Muqlah merumuskan empat ketentuan tentang tata cara dan tata letak yang sempurna pada tulisan khat Naskhi berikut ini: 1) Tarsif ترصيف (jarak huruf rapat dan teratur), 2) Ta'lif تأليف (susunan huruf terpisah dan bersambung dalam bentuk serasi), 3) . Tastir تسطير (keselarasan dan kesempurnaan hubungan satu kata dengan lainnya dalam sau garis lurus), 4) Tansil تنصيل (melukis keindahan dalam setiap sapuan garis pada setiap hurufnya).

\section{References}

Ahmad, Abd. Aziz, 'Contemporary Islamic Calligraphy Learning', 519.Icade 2020 (2021), 232-36 $<$ https://doi.org/10.2991/assehr.k.210203.049>

Dan, Perkembangan Kaligrafi, and Abdul Hakim, 'THE DEVELOPMENT OF ISLAMIC CALLIGRAPHY AND ITS URGENCY FOR THE QUR ’ ANIC MANUSCRIPTS', Jurnal Lektur Keagamaan, 19.1 (2021), 69-102 <https://doi.org/10.31291/jlk.v19i1.911>

El, D A R, Hikmah Pekanbaru, D A R El, and Hikmah Pekanbaru, 'Kemampuan Santri Dalam Menulis Khat Naskhi Pada Pelajaran Kaligrafi Di Madrasah Tsanawiyah Pondok Pesantren Dar El Hikmah Pekanbaru', 2010

Haji Harun, Makmur, 'EKSISTENSI SENI KALIGRAFI ISLAM DALAM DAKWAH: Tantangan , Peluang Dan Harapan.', October, 2015, 0-18 <https://doi.org/10.13140/RG.2.1.2949.8320>

Huda, Nurul, 'Implementasi Jenis Khat Naskhi Dalam Pembelajaran Bahasa Arab', Al Mahāra: Jurnal Pendidikan Bahasa Arab, 3.2 (2017), 291-316 <https://doi.org/10.14421/almahara.2017.032-06>

${ }^{25}$ Nurul Huda, Implementasi Jenis Khat Nashi Dalam Pembelajaran Bahasa Arab, UIN Sunan Kalijaga Yogyakarta.h.310

${ }^{26}$ Suaibi Mahbub, 'Pembelajaran Kaligrafi Pada Santri Pon-Pes. Al-Falah Lemahabang Kabupaten Luwu Utara', 2017.h.20. 
Hula, Ibnu Rawandhy N., 'AL-QAWAID AL-SITTAH DALAM RASM AL-MUSHAF (Kajian Teoritis Terhadap Enam Kaidah Pokok Dan Keunikannya Dalam Penulisan Al-Qur'an)', ed. by Ana Mariana (Gorontalo), pp. 1-33

Hula, Ibnu Rawandhy N. Agussalim Beddu Mala, الفروق الضبطية بين الرسم المصحفى و الرسم الإملائي', Al-Lisan: Jurnal Bahasa $\quad$ (e-Journal), $\quad 6.1 \quad$ 85-111 <https://doi.org/https://doi.org/10.30603/al.v6i1.1930>

Hula, Ibnu Rawandhy N, 'Ortografi Alif Ziyadah Dalam Rasm Mushaf Madinah Pada SUrah Al-Baqarah' (Malang: Jurusan Sastra Arab - Fakultas Sastra UniversitasNegeri Malang, 2020), pp. 945-65 $<$ http://prosiding.arab-um.com/index.php/konasbara>

, 'Preferensi Abu Dawud Sulaiman Bin Najjah Dalam Kaidah Rasm Al-Mushaf/Preference of Abu Dawud Sulaiman Bin Najjah In Rules of Rasm Al-Mushaf, Diwan: Jurnal Bahasa Dan Sastra Arab, 6.2 (2020) <https://doi.org/https://doi.org/10.24252/diwan.v6i2.13969>

—, Qawaid Al-Imla' Wa Al-Khat: Kaidah-Kaidah Menulis Huruf Dan Kata Arab Dan Seni Kaligrafi (IAIN Sultan Amai Gorontalo, 2016)

- Qawaid Al-Imla' 'Wa Al-Khat 1, 2015

Hula, Ibnu Rawandhy N, Berti Arsyad, Iain Sultan, Amai Gorontalo, and Universitas Muhammadiyah Gorontalo, 'Diakritik Al-Quran Menurut Preferensi Abu Dawud', 'A Jamiy: Jurnal Bahasa Dan Sastra Arab, 9.2 (2020), 265-84 <https://doi.org/http://dx.doi.org/10.31314/ajamiy.9.2.264-284.2020>

Ibnu Rawandhy Hula, 'GENEALOGI ORTOGRAFI ARAB (Sebuah Tinjauan Historis: Asal-Usul, Rumpun Bahasa Dan Rekaman Inskripsi)', Http://Journal.Umgo.Ac.Id/Index.Php/AJamiy/Index, 9.1 (2020), 16-46 <https://doi.org/DOI: http://dx.doi.org/10.31314/ajamiy.9.1.16-46.2020>

Itsnaini, Ana Shoimah, 'Peran Pembelajaran Kaligrafi Dalam Melestarikan Seni Budaya Islam', Journal of Chemical Information and Modeling, 53.9 (2013), 1689-99 <https://doi.org/10.1017/CBO9781107415324.004>

Mahbub, Suaibi, 'Pembelajaran Kaligrafi Pada Santri Pon-Pes. Al-Falah Lemahabang Kabupaten Luwu Utara', 2017

Makmur, Harun, and Yusof Abdullah, 'Manifestasi Khat Naskhi Sebagai Tulisan Asas Al-Quran: Kajian Terhadap Jenis Khat Naskhi Sebagai Tulisan Asas Al- Quran Mushaf Uthmani', January, 2011

Mawardi, M, 'Penerjemahan Komunikatif Buku Asrar Al-Rasm Fi Khat Al-Naskhi Karya Mohamed Amzil', Skripsi, 2012, 1-154

Nurhidayat, Furqon, Juju Masunah, and Tri Karyono, 'Arabic Calligraphy in the Art of Glass Painting From Cirebon by Raffan S. Hasyim’, 519.Icade 2020 (2021), 52-56 <https://doi.org/10.2991/assehr.k.210203.011>

Rahmat, Ali Fitriana, 'Ibnu Muqlah (W. 328 H): Sejarah Dan Sumbangsihnya Dalam Penulisan AlQur'an', Jurnal Al-Fanar, 4.1 (2021), 45-62 <https://doi.org/10.33511/alfanar.v4n1.45-62>

Usman, 'Korelasi Penguasaan Kaligrafi (Khat Arab) Dengan Kterampilan Menulis Bahasa Arab Siswa Kelas VII MTs Darul Muhajirin Putra Praya Lombok Tengah Tahun Pelajaran 2016-2017', Вестник Росздравнадзора, 2017

Harun, Makmur Haji. "Eksistensi Seni Kaligrafi Islam dalam Dakwah: Tantangan, Peluang dan Harapan." (2015).

Huda, Nurul. "Implementasi Jenis Khat Naskhi dalam Pembelajaran Bahasa Arab." al Mahāra: Jurnal Pendidikan Bahasa Arab 3.2 (2017): 287-312.

Hula, Ibnu Rawandhy N. Qawaid Al-Imla Wa Al-Khat: Kaidah-kaidah Menulis Huruf dan Kata Arab dan Seni Kaligrafi. IAIN Sultan Amai Gorontalo, 2016.

Itsnaini, Ana Shoimah. Peran Pembelajaran Kaligrafi Dalam Melestarikan Seni Budaya Islam (Studi Kasus di MA YP KH Syamsuddin Durisawo Nologaten Ponorogo). Diss. IAIN Ponorogo, 2019.

Makmur, DR, and Sejarah Dan Tamadun Islam. "Manifestasi Khat Naskhi Sebagai Tulisan Asas AlQur'an: Kajian Terhadap Jenis Khat Naskhi sebagai Tulisan Asas dalam al-Qur'an Mushaf Uthmani."

Maryono, Maryono. "Nilai-Nilai Pendidikan Dalam Seni Kaligrafi Karya Syaiful Adnan." Wahana Islamika: Jurnal Studi KeIslaman 4.1 (2018): 1-24..

Mawardi, M. Penerjemahan Komunikatif BukuAsrâr Al-Rasm Fî Khat Al-Naskhi Karya Mohamed Amzil. BS thesis. Fakultas Adab \& Humaniora, 2018 
Pujiati, Pujiati. "Kaligrafi Arab Digital Ayat Al-qur'an Di Dunia Maya." MIQOT: Jurnal Ilmu-ilmu KeIslaman 40.1 (2016).

Suaibi, Mahbub. Pembelajaran Kaligrafi pada Santri Pon-Pes. Al-Falah Lemahabang Kabupaten Luwu Utara. Diss. Universitas Islam Negeri Alauddin Makassar, 2017.

Usman, Usman. Korelasi penguasaan kaligrafi (khat arab) dengan keterampilan menulis bahasa arab siswa kelas VII MTs Darul Muhajirin Putra Praya Lombok Tengah Tahun Pelajaran 2016/2017. Diss. Universitas Islam Negeri Mataram, 2017.

Wijaya, Seno. Kemampuan Santri Dalam Menulis Khat Naskhi Pada Pelajaran Kaligrafi Di Madrasah Tsanawiyah Pondok Pesantren Dar El Hikmah Pekanbaru. Diss. Universitas Islam Negeri Sultan Syarif Kasim Riau, 2010. 